\title{
ORGANIZATIONAL MODEL OF PALLIATIVE CARE IN THE REPUBLIC OF CROATIA - WHERE ARE WE TODAY?
}

\author{
LIDIJA FUMIĆ DUNKIĆ ${ }^{1}$ and ANTONIA KUSTURA² \\ ${ }^{1}$ Department of Anesthesiology, Intensive medicine and Pain treatment, \\ Sestre milosrdnice University Hospital Center, Zagreb, Croatia; \\ ${ }^{2}$ Mobile Palliative Care Team, Health Care Center, Zagreb, Croatia
}

\section{Summary}

The Republic of Croatia is in the process of establishing a palliative care system in all aspects of the health care system according to The National Program for Palliative Care Development 2017-2020.

A curative and palliative treatment should be carried out simultaneously, from the time the diagnosis of life-limiting illnesses was made, as the illnesses progresses with reducing the share of curative treatment and increasing the proportion of palliative care. With the help of a well-organized palliative care system, the patient and family can have dignified care and quality of life.

Still, a large number of health professionals are not even aware of the existence and option of palliative care. Therefore, it is essential that the National Program for Palliative Care Development also continues the education of palliative care that should include all health workers.

Implementation of palliative care into the health care system is a long-term process, but important steps have been taken so far, especially in urban areas, Zagreb and Rijeka.

KEY WORDS: organizational model of pallative care, pallaliative care, quality of life, integrative care

\section{ORGANIZACIJSKI MODEL PALIJATIVNE SKRBI U REPUBLICI HRVATSKOJ - GDJE SMO DANAS?}

\section{Sažetak:}

U Republici Hrvatskoj u tijeku je proces uspostave sustava palijativne skrbi u sve elemente zdravstvenog sustava, prema Nacionalnom programu razvoja palijativne skrbi 2017.-2020.

Od trenutka postavljanja dijagnoze bi trebalo paralelno provoditi kurativno i palijativno liječenje, s tim da se, kako bolest napreduje, smanjuje udio kurativnog liječenja, a povećava udio palijativne skrbi. Uz pomoć dobro organiziranog sustava palijativne skrbi bolesnik i obitelj mogu imati zadovoljavajuću skrb i kvalitetu života.

Još uvijek velik broj zdravstvenih djelatnika nije upoznat s postojanjem i opcijom palijativne skrbi. Stoga je bitno da se po Nacionalnom programu razvoja palijativne skrbi provede i nastavak edukacije iz palijativne skrbi koja bi trebao uključiti sve zdravstvene radnike.

Implementacija palijativne skrbi u sustav zdravstva je dugotrajan proces, ali već do sada su učinjeni značajni koraci, naročito u urbanim sredinama, Zagrebu i Rijeci.

KLJUČNE RIJEČI: organizacijski model palijatione skrbi, palijativna skrb, kvaliteta života, integrirana skrb 
Palliative care is comprehensive, specialized care for people with life-limiting illnesses, with goal to improve the quality of life of patients and their families. The Republic of Croatia is in the process of establishing a palliative care system in all aspects of the health care system. Currently, the National Program for Palliative Care Development in the Republic of Croatia 2017-2020 is being implemented, which is a continuation of the implementation of the palliative care system and is complementary to the Strategic Plan for the Development of Palliative Care in the Republic of Croatia for the period 2014-2016. Both documents are produced in accordance with the White Book on standards and norms for hospice and palliative care in Europe.

There are three levels of palliative care.

The first level is the Palliative Care Approach that applies to all professionals who should be informed about palliative care and everything that it provides.

The second level is General Palliative Care that includes all professionals where palliative care is not their primary job, but in their work they often participate in caring for palliative patients where they can recognize and solve uncomplicated symptoms.

Table 1.

OVERVIEW OF PALLIATIVE CARE SERVICES ADAPTED TO THE ORGANIZATION OF THE HEALTH CARE SYSTEM OF THE REPUBLIC OF CROATIA ACCORDING TO THE RECOMMENDATIONS OF THE EUROPEAN ASSOCIATION FOR PALLIATIVE CARE

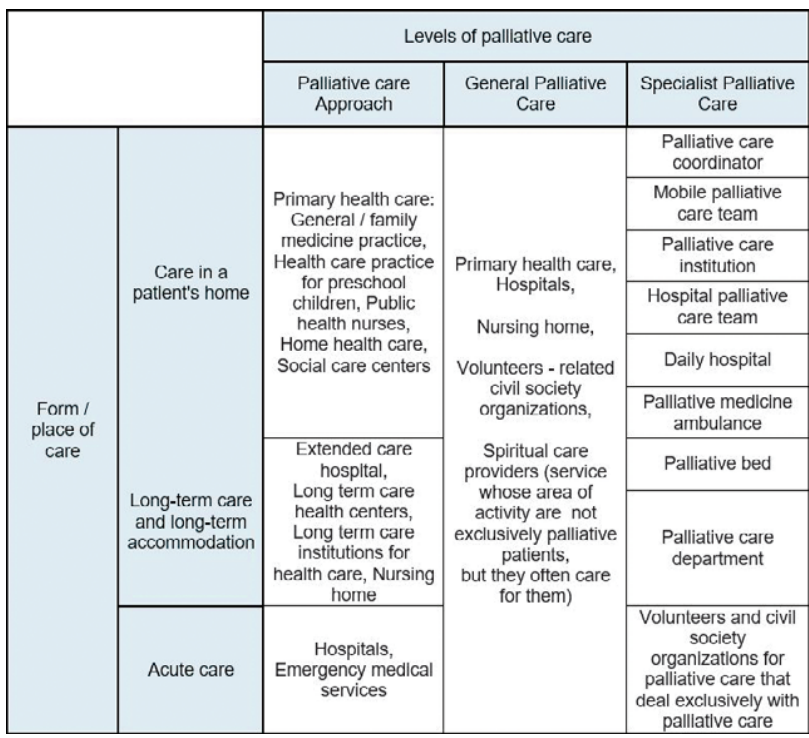

The third level is Specialist Palliative Care, which includes well-trained health professionals and well-educated psychologists and social workers who exclusively deal with palliative care and volunteers and civil society organizations for palliative care.

In Croatia, we observe the simultaneous implementation and the development of organizational forms that have been established. We are in the process of establishing protocols of communication between the stakeholders of palliative care: hospital palliative care team, palliative care coordinator, family medicine doctor, mobile palliative team, public health nurses, home health care nurse, home aids and equipment center, social workers, volunteers, spiritual care providers.

All three levels are of great importance, but unfortunately, a large number of health professionals are not even aware of the existence and option of palliative care. Therefore, it is essential that the National Program for Palliative Care Development also continues the education of palliative care that should include all health workers.

In a patient with a diagnosis of life-limiting illnesses, a curative and palliative treatment should be carried out simultaneously from the time the diagnosis was made, as the disease progresses, reducing the share of curative treatment and increasing the proportion of palliative care.

Figure 1 shows the change and overlap of curative and palliative care with disease progression.

Since we are currently developing palliative care, which includes limited capabilities and resources, we are now focusing more on patients who are at the end of active treatment or who have completed active treatment. Mostly, it is about the last twelve months of their lives.

It would be ideal that a leading physician in the treatment process, an oncologist, a family physician or other physician involved in the treatment process, the person with whom the patient is most comfortable, to have a holistic approach to the palliative patient and a plan to fit his needs. It is important to emphasize that the medicine does not leave the patient in this way but rather care for the patient with the aim of increasing the quality of their life and lives of the family members who care for the patient. From the moment of diagnosis, the most crucial thing is open communication with 


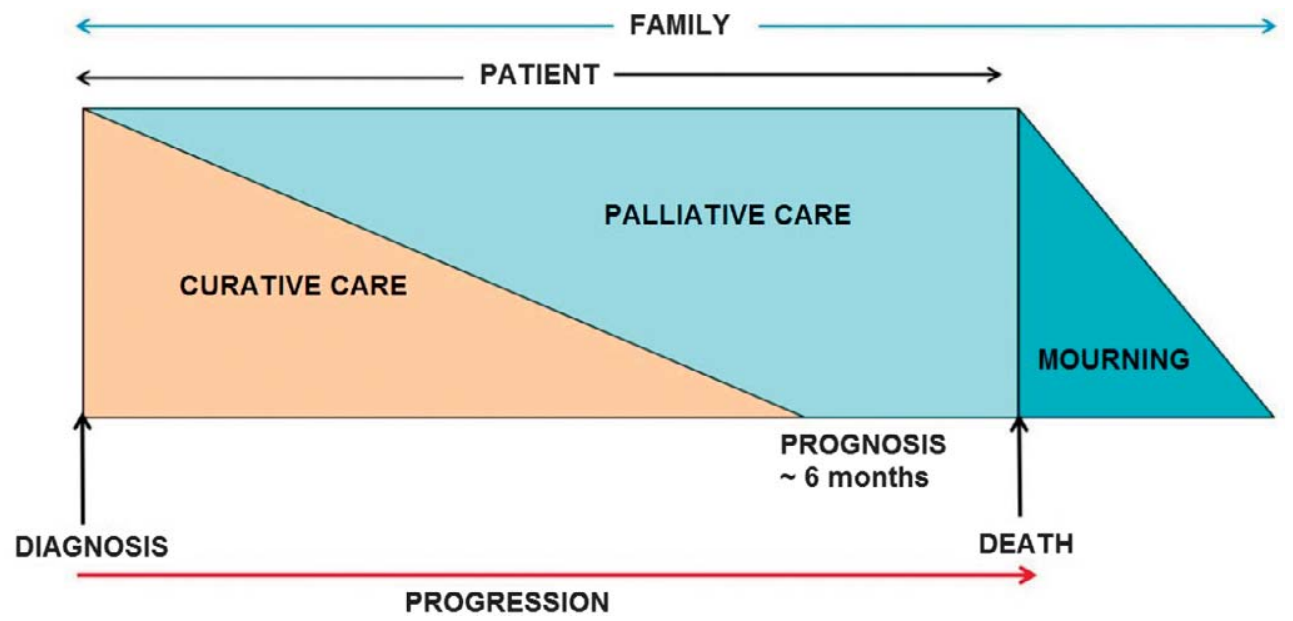

Figure 1. The change and overlap of curative and palliative care with disease progression.

the patient and the family. The palliative approach gives the possibility of an open conversation about the desires of dying and dying itself.

With the help of a well-organized palliative care system, the patient and family can have dignified care and quality of dying and death.

The hospital palliative care team recognizes the palliative patient during hospitalization and assesses the leading symptoms of the patient as well as their needs. The aim is the control of symptoms and to have therapy adjusted and defined at the time of discharge. The patient is discharged from the hospital with the palliative patient code $\mathrm{Z} 51.5$ and the recommended therapy. It is also important that patients' needs are assessed before further involvement of the palliative care coordinator.

The Palliative Care Coordinator has the task of coordinating the involvement of all other stakeholders in palliative care. In the case of home care, adequate conditions should be provided, all necessary aids and medications (which is especially important for opioid medicines whose procurement is sometimes a multi-day process). A home health care nurse and mobile palliative care team members provide health care in the patient's home according to the indication. It is often necessary to involve volunteers and civil society organizations as non-health workers.

The leading physician or the hospital team who takes care of the patient notifies the mobile palliative care team (a specialist doctor and a nurse) of the existence of a palliative patient. Mobile pal- liative care team takes over the care and helps in symptoms control through regular visits and telephone consultations. They provide comprehensive palliative care which includes a multimodal and multidisciplinary approach (members of the extended team are social worker, psychologist, spiritual care provider and other professionals).

At the time when symptoms can no longer be controlled at home, the patient is referred to the Hospital Emergency Department in order to avoid unnecessary waiting and extensive workup that only increases patient suffering without adequate help. In the case of unregulated symptoms requiring hospitalization, the patient is admitted to the Palliative Care Department. Duration of the hospitalization is determined by complete control of the symptoms. Less often, when the severity of the symptomatic situation so requires, the patient remains in the palliative care department until death.

A well-organized palliative care system minimizes the number of interventions for out-hospital and hospital emergency services. The palliative care system requires good connections and continuous cooperation of all stakeholders stressing the patient's and family's quality of life and dignified death.

In healthcare facilities in the City of Zagreb, palliative care has been organized on three levels, as primary level (health centers, nursing homes), secondary level (specialized hospital) and tertiary level (clinics, clinical hospital). 


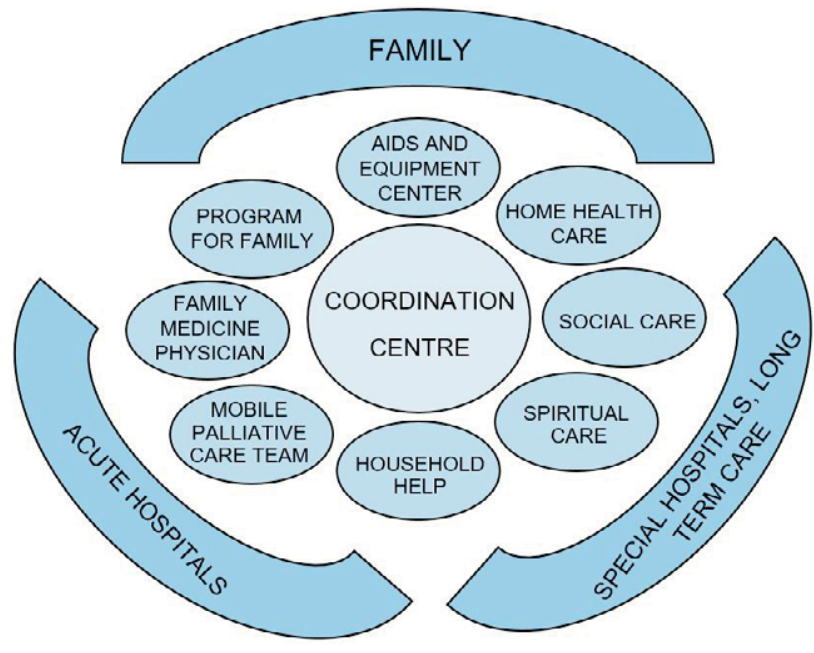

Figure 2. Stakeholders of palliative care.

What does it look like in practice?

In the course of curative treatment, the team of specialists and other health professionals is involved in the care of patients. Unfortunately, however, we often see the failure to recognize patients as a palliative patient, and such patients die, accompanied by numerous symptoms that could be identified, alleviated or resolved in time. Control of symptoms, both physical and psychological, is one of the critical elements of palliative care.

The patient can be identified as a potentially palliative by anyone. The challenge is to identify and include palliative care on time! It is important that anyone of the doctors and nurses from the hospital or outpatient emergency, the family doctor or health care facility recognizes the patient as potentially palliative and instructs him what to do next. The national guidelines and recommendations for the provision and development of palliative care give professionals the opportunity to get involved themselves. The palliative care specialists are trying to advertise these guidelines and provide the information both to professionals and to the general public.

What is expected in the future?

The current biggest problem is the lack in the health sector. Given the general lack of health care workers and the severity of work with palliative patients, it is important to find appropriate stimulation to attract as many staff members as possible into this branch of medicine. The National Program for Palliative Care Development provides slots to meet all the requirements precisely, to achieve all the necessary conditions according to the European and world standards.

Since it is about implementing a relatively new branch of medicine, at least in our system, it is clear that the professionals themselves must go through appropriate education.

Palliative care education is beginning to develop on several levels. At the medical school level, there is education on palliative care in the form of a compulsory or optional subject, in other curricula nursing, social work, and related specializations as well. Some medical schools have additional subjects on palliative care or permanent training courses for all professionals and volunteers involved in palliative care. Furthermore, education on palliative care is often in the form of workshops, lectures or courses are organized by the hospital/health care center for their employees. It is important that for every professional and for every form of palliative care there is a corresponding education that naturally does not have to be of the same range.

Professionals who are in daily contact with palliative patients should be involved in the regular supervision process. Supervision improves the behavior of people in their professional roles and leads to the continuous development of professionals, and results in improved work and functioning of the professionals themselves, whose ultimate goal, in this case, is better care for patients.

Implementation of palliative care into the health care system is a long-term process, but important steps have been taken so far, especially in urban areas, Zagreb and Rijeka. It is crucial to maintain the continuity of the operation and implementation of the palliative care system.

Palliative care is active, comprehensive care for patients whose illness does not respond to treatment procedures. The most important is the control of pain, or other symptoms, and of social, psychological and spiritual problems, whether at home or in an institution. Its scope includes the patient, the family, and the community.

\section{REFERENCES:}

1. National Program of Palliative Care Development in the Republic of Croatia 2017-2020. https://zdravlje. gov.hr/nacionalni-programi-projekti-i-strategije/na- 
cionalne-strategije/provedba-strateskog-plana-razvoja-palijativne-skrbi/nacionalni-program-razvoja-palijativne-skrbi-u-republici-hrvatskoj-2017-2020/3094. Accessed on November 9th 2018.

2. WHO Definition of Palliative Care. https://www.who. int/cancer/palliative/definition/en/ Accessed on November 9th 2018.

3. White Book on standards and norms for hospice and palliative care in Europe. EAPC dementia task force. https://www.eapcnet.eu/publications/eapc-documents-in-other-languages/PID/1207/ev/1/CategoryID/ 38/CategoryName/Croatian Accessed on November 9th 2018.

4. National guidelines for the work of outpatient and hospital emergency medical services with patients requiring palliative care, Croatian Institute of Emergen- cy Medicine. http://kbc-rijeka.hr/wp-content/uploads/ 2016/05/Nacionalne-smjernice-za-rad-izvanbolnickei-bolnicke.pdf Accessed on November 9th 2018.

5. Službeni glasnik grada Zagreba 2018, November 2nd; 23: Plan razvoja palijativne skrbi u gradu Zagrebu [Plan for the development of palliative care in the City of Zagreb].

Corresponding author: Lidija Dunkić Fumić, Department of Anesthesiology, Intensive Medicine and Pain Treatment, Sestre milosrdnice University Hospital Center, Vinogradska 29, 10000 Zagreb, Croatia. e-mail: lidija.fumic.dunkic@gmail.com 